\title{
Enteric bacterial pathogen detection in southern sea otters (Enhydra lutris nereis) is associated with coastal urbanization and freshwater runoff
}

\author{
Melissa A. Miller ${ }^{1 *}$, Barbara A. Byrne ${ }^{2,3}$, Spencer S. JANG ${ }^{3}$, Erin M. Dodd ${ }^{1}$, \\ Elene Dorfmeier ${ }^{1}$, Michael D. Harris ${ }^{1}$, Jack Ames ${ }^{1}$, David Paradies ${ }^{4}$, \\ Karen Worcester ${ }^{5}$, David A. Jessup ${ }^{1}$, Woutrina A. Miller ${ }^{2}$ \\ ${ }^{1}$ California Department of Fish and Game, Marine Wildlife Veterinary Care and Research Center, \\ 1451 Shaffer Road, Santa Cruz, CA, 95060, USA \\ 2 Department of Pathology, Microbiology and Immunology, School of Veterinary Medicine, \\ University of California, Davis, CA, 95616, USA \\ ${ }^{3}$ Microbiology Laboratory, Veterinary Medical Teaching Hospital, University of California, Davis, \\ CA, 95616, USA \\ ${ }^{4}$ Bay Foundation of Morro Bay, 601 Embarcadero, Suite 11, Morro Bay, CA, 93442, USA \\ ${ }^{5}$ Central Coast Regional Water Quality Control Board, 81 Higuera St., Suite 200, San Luis Obispo, \\ CA, 93401, USA
}

(Received 23 November 2008; accepted 31 August 2009)

\begin{abstract}
Although protected for nearly a century, California's sea otters have been slow to recover, in part due to exposure to fecally-associated protozoal pathogens like Toxoplasma gondii and Sarcocystis neurona. However, potential impacts from exposure to fecal bacteria have not been systematically explored. Using selective media, we examined feces from live and dead sea otters from California for specific enteric bacterial pathogens (Campylobacter, Salmonella, Clostridium perfringens, C. difficile and Escherichia coli O157:H7), and pathogens endemic to the marine environment (Vibrio cholerae, V. parahaemolyticus and Plesiomonas shigelloides). We evaluated statistical associations between detection of these pathogens in otter feces and demographic or environmental risk factors for otter exposure, and found that dead otters were more likely to test positive for $C$. perfringens, Campylobacter and $V$. parahaemolyticus than were live otters. Otters from more urbanized coastlines and areas with high freshwater runoff (near outflows of rivers or streams) were more likely to test positive for one or more of these bacterial pathogens. Other risk factors for bacterial detection in otters included male gender and fecal samples collected during the rainy season when surface runoff is maximal. Similar risk factors were reported in prior studies of pathogen exposure for California otters and their invertebrate prey, suggesting that land-sea transfer and/or facilitation of pathogen survival in degraded coastal marine habitat may be impacting sea otter recovery. Because otters and humans share many of the same foods, our findings may also have implications for human health.
\end{abstract}

\section{Campylobacter / Clostridium / sea otter / Salmonella / Vibrio}

\footnotetext{
* Corresponding author: mmiller@ospr.dfg.ca.gov

This is an Open Access article distributed under the terms of the Creative Commons Attribution-Noncommercial License (http://creativecommons.org/licenses/by-nc/3.0/), which permits unrestricted use, distribution, and reproduction in any noncommercial medium, provided the original work is properly cited.
} 


\section{INTRODUCTION}

Fecal contamination of coastal marine habitat is a global problem, manifesting as increased beach closures, water contact-associated illness and shellfish harvest restrictions [17, 19]. In some countries, identifying waters that are not fecally-impaired has become a challenge [5, $15,23,38]$. Once bacteria, viruses and protozoa enter the ocean, invertebrates can efficiently concentrate these potential pathogens through filter-feeding activity [17, 25-29]. Bacterial groups that are considered markers for fecal contamination include Salmonella enterica, Campylobacter, Escherichia coli, Clostridium perfringens and $C$. difficile [20, 29, 34]. Human disease associated with these pathogens often peaks after storms, floods or sewage spills transfer contaminated effluent to local marine ecosystems [2]. In contrast, some other potential pathogens like Vibrio parahaemolyticus, V. cholerae and Plesiomonas shigelloides are halophilic, thermophilic species that thrive in estuarine and marine environments. These latter bacteria pose the greatest human health risk during periods of warm, dry weather $[14,23,32,38]$.

Marine mammals swim and feed in fecallypolluted coastal waters in spite of beach or seafood harvest closures and some species prey on filter-feeding invertebrates. As a result, wildlife exposure to enteric pathogens may be significantly higher than for humans utilizing the same areas [21]. One example is the southern sea otter (Enhydra lutris nereis), a federally protected sub-species found only along the California coast. Despite decades of legal protection, southern sea otter population recovery has been hindered by high mortality, including numerous deaths due to protozoa that are shed in the feces of terrestrial hosts [25, 26]. Prior epidemiological studies suggest that these infections are of terrestrial origin and are associated with sea otter exposure to coastal freshwater runoff [24]. Here we provide preliminary evidence to expand the range of land-based pathogens impacting southern sea otters to include enteric bacteria.

Sea otters are at high risk for exposure to pathogenic bacteria entering the nearshore marine environment due to their unique biology: (1) They often feed within or adjacent to coastal surface water drainages [24]; (2) Many favored prey items can concentrate bacteria, parasites and viruses in their tissues [25, 27-29]; (3) Sea otters have a very high metabolic rate, typically consuming $25 \%$ to $30 \%$ of their own weight in invertebrates each day [31]; (4) Otters sometimes excavate marine sediments to capture prey; in polluted habitat these sediments may support high concentrations of enteric bacteria [21] and (5) During storms, some otters move into sheltered bays to seek protection from high waves. These enclosed water bodies are exposed to high surface water influxes during storms. Dilution is further inhibited by narrow bay openings and limited tidal flushing, thus placing sea otters directly in the path of concentrated plumes of land-based pollution.

To determine the range of bacteria present and to trace potential sources for otter exposure, we screened feces from $>240$ southern sea otters for infection by the most common opportunistic enteric bacterial pathogens of humans and terrestrial animals. Using epidemiological techniques, relationships were explored between detection of these enteric pathogens in otters and various risk factors for exposure, including the degree of coastal urbanization and proximity to large plumes of municipal sewage or freshwater runoff. Our results provide important clues regarding the potential impacts of coastal development and surface water discharge on the recovery of a threatened marine mammal.

\section{MATERIALS AND METHODS}

\subsection{Sample collection}

Live and dead otters were sampled between 2000 and 2005 throughout California (Fig. 1). Each otter's gender, age and location were recorded during capture or postmortem examination. Feces from live otters were collected per rectum, from clean transport cages, or from haulouts during low tide. Feces were also collected during necropsy of freshly dead otters $(<72 \mathrm{~h}$ postmortem under refrigeration) at the California Department of Fish and Game (CDFG) 


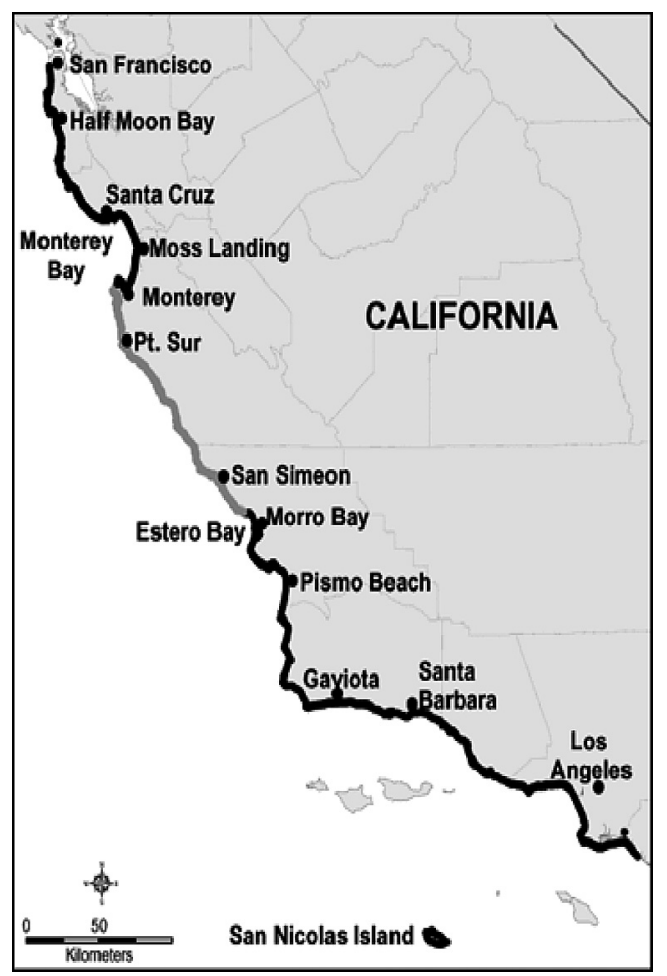

Figure 1. Map of central and southern California, showing the sample range for sea otters. Animals were sampled opportunistically from San Francisco southward, but most were obtained between Santa Cruz and Santa Barbara. Data were pooled into 3 groups for some analyses: Northern (thick black coastal line from San Francisco to Monterey), central coast (grey line from Monterey to Morro Bay) and south coast (thick black line from Morro Bay southward, inclusive of San Nicholas Island). The northern and southern regions are more urbanized, compared to the central coast.

Marine Wildlife Veterinary Care and Research Center (MWVCRC). Samples were refrigerated and sent overnight to the UC Davis School of Veterinary Medicine (Davis, CA, USA) for bacterial isolation and identification.

\subsection{Bacterial detection}

Feces were screened for the enteric pathogens Campylobacter, Salmonella, P. shigelloides, E. coli O157:H7, C. perfringens, $C$. difficile and Vibrio spp. (including $V$. cholerae, V. parahaemolyticus and $V$. alginolyticus) using standard media and enrichment techniques. Samples were examined at 24 and $48 \mathrm{~h}$ of incubation at $35^{\circ} \mathrm{C}$ for the presence of bacteria and at least 6 distinct colony types were selected from each plate for identification. Distinct colony types were subcultured onto fresh media and characterized using Gram stains, selective media, biochemical tests and identification kits (API 20E, API NE and API Strep: BioMerieux, Hazelwood, MO, USA). Campylobacter spp. were isolated using cefoperazone, vancomycin and amphotericin B-supplemented (CVA) blood agar with 5\% sheep blood, followed by a gram stain and standard biochemical testing, including sensitivity to cephalothin $(30 \mu \mathrm{g})$ and nalidixic acid $(30 \mu \mathrm{g}), 3 \%$ catalase and $1 \%$ hippurate urease and nitrate reduction. Cultures were enriched for Salmonella using selenite broth incubated for $24 \mathrm{~h}$ before subculturing onto xylose lysine tergitol4 (XLT4) agar. Colonies exhibiting morphology consistent with Salmonella were identified using standard biochemical tests and bacterial agglutination using Poly $\mathrm{O}$ antiserum and specific antisera (Fisher Scientific, Fair Lawn, NJ, USA). Serotyping was confirmed at the National Veterinary Services Laboratory (Ames, IA, USA). Vibrio spp. were detected using thiosulfate citrate bile salts sucrose (TCBS) agar. Clostridium perfringens was grown on egg yolk agar (EYA) incubated under anaerobic conditions and isolates were confirmed with positive lecithinase and CAMP reaction tests. Plesiomonas shigelloides was isolated on MacConkey plates and colonies with appropriate morphology were identified using API20E strips (BioMerieux). Screening for E. coli O157:H7 was performed on cefixime potassium tellurite sorbitol MacConkey (CT SMAC) plates and colorless colonies were evaluated using a latex agglutination test (Remel, Lenexa, KS, USA) with E. coli $\mathrm{O} 157: \mathrm{H} 7$ antiserum. Where necessary, partial DNA sequencing of the 16S ribosomal RNA gene was utilized to confirm the identity of isolates.

Starting in 2002, broth enrichment techniques were used to enhance detection of $V$. cholerae and $C$. difficile in otter feces. For Vibrio screening, swabs or feces were placed in alkaline peptone water and incubated $12-24 \mathrm{~h}$ at $35^{\circ} \mathrm{C}$ prior to subculture on TCBS agar. Isolates were identified by reaction in triple sugar iron agar, spot oxidase and indole tests, urease production and API20E tests (BioMerieux). Vibrio cholerae isolates were evaluated using specific antisera to identify O1+ serotypes (Becton, Dickinson and Co., Sparks, MD, USA). For isolation of $C$. difficile, fecal samples were placed in cycloserine-cefoxitin fructose broth and incubated anaerobically for $12-24 \mathrm{~h}$, followed 
by subculture onto cycloserine-cefoxitin fructose agar (VM Biological Media Services, UC Davis, Davis, CA, USA). Yellow colonies with appropriate morphology were subcultured onto sheep blood agar plates (BAP) and evaluated using a Pro Disk test (Remel, Lenexa, KS, USA), with colonies testing positive identified as $C$. difficile.

\subsection{Characterization of risk factors for pathogen exposure}

Potential risk factors were defined for each otter, including gender, location, sample period, live-dead status and proximity to centers of coastal urbanization and major surface water or municipal sewage outflows. Effects of age and nutritional condition were not assessed because most sampled otters were adults and nutritional condition was not available for all animals. Each otter stranding or sampling location along the California coast was determined to the nearest $0.5 \mathrm{~km}$ as previously described [24]. Samples encompassed the coast between San Francisco and Long Beach, including San Nicolas Island (Fig. 1). The sea otter range was also divided into three regions, designated as north (San Francisco through Monterey Bay), central (the rural central coast) and south (Estero Bay southward, inclusive of San Nicholas Island) for some analyses (Fig. 1). Coastal human population density was determined using United States 2000 census data ${ }^{1}$, pooled into 5 groups: $<100\left(<38 / \mathrm{km}^{2}\right), \quad 100$ to 1000 (38 to $\left.386 / \mathrm{km}^{2}\right),>1000$ to $3000 \quad(>386$ to $\left.1158 / \mathrm{km}^{2}\right),>3000$ to 6000 ( $>1158$ to $2316 /$ $\mathrm{km}^{2}$ ) and $>6000$ persons $/ \mathrm{mile}^{2} \quad\left(>2316 / \mathrm{km}^{2}\right)$. Each otter was assigned the coastal human population density nearest to their sample location. Otters sampled during the warm, dry season (June through November) were pooled as "dry season samples" for comparison with otters sampled during the wetter and cooler months (December through May).

Quantification of freshwater outflow was determined using the outfall locations of each stream or river along the California coast. Discharge from each watershed was estimated as previously described [24] using an exponential dilution model. Exposure values for each otter were determined by weighting both proximity to the nearest river or stream mouth and the total annual outflow in acre-feet/ year: $\leq 10000\left(\leq 1.23 \times 10^{7} \mathrm{~m}^{3} /\right.$ year $),>10000$ to $100000\left(>1.23 \times 10^{7}\right.$ to $1.23 \times 10^{8} \mathrm{~m}^{3} /$ year $)$ and $>100000\left(>1.23 \times 10^{8} \mathrm{~m}^{3} /\right.$ year $)$. Freshwater influence was considered negligible if $<10000$ acre-feet/year.

\footnotetext{
${ }_{1}$ www.geographynetwork.com.
}

Relative exposure to municipal sewage was determined using the same approach. Sewage discharge locations and volumes from National Pollutant Discharge System (NPDES) records were mapped using the $0.5 \mathrm{~km}$ coastal units described above. Influences of proximity and effluent volume exposure were estimated using an exponential dilution model [24] as $<1 \quad\left(<1.23 \times 10^{3} \mathrm{~m}^{3} /\right.$ year $), \quad 1$ to 4000 $\left(1.23 \times 10^{3}\right.$ to $4.93 \times 10^{6} \mathrm{~m}^{3} /$ year $)$ or $\geq 4001$ acre-feet/year $\left(>4.93 \times 10^{6} \mathrm{~m}^{3} /\right.$ year). Sewage and freshwater flows were not corrected for seasonal variation or effects due to wind, currents or coastal geography.

\subsection{Epidemiologic analysis}

Univariate and multivariate logistic regression approaches were used in a forward and backward selecting manner to investigate associations between pathogen detection in sea otters and demographic or environmental risk factors. Univariate analyses examine each risk factor individually with regard to presence or absence of the bacterial outcome of interest, but multivariate models are most informative because they produce adjusted odds ratios that simultaneously measure the strength of associations between multiple risk factors and the bacterial outcome of interest. Analyses were completed using Stata 10.0 (StataCorp., College Station, TX, USA). Spatial relationships between bacterial pathogen detection and otter location were evaluated using SaTScan 2.1 ${ }^{2}$. Distributions of infected versus non-infected otters were compared using a Bernoulli-based spatial model with a $20 \mathrm{~km}$ maximum radius [18], and data were analyzed for both higher and lower than expected clusters of bacterial infection. Space-time analysis ( $20 \mathrm{~km}$ radius, 30 day time window) was performed only for dead otters because they were collected continuously throughout the study, whereas live otters were sampled sporadically. $p$ values $<0.1$ were considered statistically significant.

\section{RESULTS}

\subsection{Sample collection and bacterial detection}

Between 2000 and 2005, feces were processed from 244 sea otters for isolation of Salmonella, Campylobacter, C. perfringens,

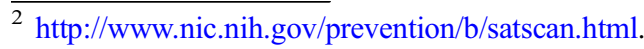


Table I. Proportion of opportunistic enteric bacterial pathogens in sea otter feces using selective media.

\begin{tabular}{lccc}
\hline Bacterial species & All sampled otters (\%) & Prevalence, live otters $^{\mathrm{a}}(\%)$ & Prevalence, dead otters $^{\mathrm{b}}(\%)$ \\
\hline C. perfringens & 27.5 & 13 & 46 \\
V. parahemolyticus & 19.3 & 18 & 21 \\
V. alginolyticus & 17.3 & 23 & 10 \\
Campylobacter spp. & 6.5 & 3 & 11 \\
C. difficile & 6.0 & 4 & 8 \\
P. shigelloides & 5.3 & 4 & 7 \\
Other Vibrio spp. & 4.8 & 7 & 2 \\
V. cholerae & 2.5 & 2 & 3 \\
Salmonella spp. & 1.4 & 1 & 2 \\
V. fluvialis & 0.6 & 1 & 0 \\
E. coli $\mathrm{O} 157: \mathrm{H} 7$ & 0 & 0 & 0 \\
\hline
\end{tabular}

${ }^{\text {a }} n=137$ live southern sea otters, except for $C$. difficile and $V$. cholerae, where $n=96$ otters.

${ }^{\mathrm{b}} n=107$ fresh dead sea otters, except for $C$. difficile and $V$. cholerae, where $n=98$ otters.

C. difficile, P. shigelloides, E. coli O157:H7, $V$. cholerae, V. parahaemolyticus and V. alginolyticus. Over half of the samples $(n=137)$ were from live otters and the remainder $(n=107)$ were obtained postmortem. Age distributions were similar between live and dead otters, with 5 immatures and 105 adults sampled during captures and 11 immatures and 96 adults sampled at necropsy. The gender distribution was 47 live males and 63 females, and 45 dead males and 62 females. Gender and age were unknown for 27 otter scat collected at haulouts. Animals were sampled between Half Moon Bay and Long Beach, inclusive of San Nicholas Island (Fig. 1). However, the majority $(n=219)$ were sampled between Santa Cruz and Santa Barbara.

The proportions of otters testing positive for opportunistic bacterial pathogens are summarized in Table I. Most frequently isolated were C. perfringens (27.5\% of otters), V. parahaemolyticus (19.3\%), V. alginolyticus (17.3\%), Campylobacter spp. (6.5\%), C. difficile (6.0\%) and $P$. shigelloides $(5.3 \%)$. Using TCBS agar, $2.5 \%$ of otters tested positive for non-O1 $\mathrm{V}$. cholerae, but none were positive for $\mathrm{O} 1+V$. cholerae $(n=96)$. Salmonella enterica serovars were isolated from $1.4 \%$ of otters, including $S$. Typhimurium, $S$. Newport and a nontypeable Salmonella spp. Of 17 Campylobacter isolates, 4 were most similar to $C$. coli, 3 resembled C. lari and 10 were untypeable on conventional biochemical tests. Of the bacteria screened for in this study, only E. coli O157:H7 was never isolated.

\subsection{Characterization of risk factors and epidemiologic analyses}

Feces were sampled during the wet $(n=115)$ and dry $(n=139)$ seasons from the north coast $(n=81)$, the central (Big Sur) coast $(n=81)$ and the south coast $(n=82$, including 20 otters from San Nicolas Island) (Fig. 1). The north and south coasts are more heavily urbanized, while the central coast is sparsely populated by humans. Clostridium difficile was 3 times more likely to be detected in otters from the north and central regions $(p=0.005)$, and north coast otters were twice as likely to test positive for $\geq 1$ opportunistic enteric bacteria $(p=0.034)$ than south coast otters. Vibrio alginolyticus was 6 times more common in central coast otters, compared to south coast otters $(p<0.001)$.

\subsubsection{Univariate analyses}

Necropsied otters were 4 times more likely to test positive for Salmonella or Campylobacter $(p=0.01), 5$ times more likely to test positive for $C$. perfringens $(p<0.001)$ and 3 times more likely to be infected with $\geq 1$ opportunistic enteric pathogen $(p<0.001)$ than live otters. In contrast, live otters were 3 times more likely 
to test positive for $V$. alginolyticus ( $p=0.005$ ). Males were 3 times more likely to test positive for $V$. cholerae or $V$. parahaemolyticus ( $p=0.003)$, but less likely to be positive for $C$. difficile $(p=0.04)$ and $V$. alginolyticus $(p=0.003)$ than females. Otters from more urbanized coastlines were 5.7 times more likely to test positive for Campylobacter or Salmonella $(p=0.05), 5.7$ times more likely to test positive for $P$. shigelloides $(p=0.05)$ and 3.8 times more likely to be infected with $V$. cholerae or $V$. parahaemolyticus $(p=0.03)$ than those from more rural areas. Otters from urbanized coastlines were 2.4 times more likely to carry $\geq 1$ opportunistic enteric bacterial pathogen than those from rural areas $(p=0.04)$. Otters sampled near areas of high freshwater outflow were 3.1 times more likely to test positive for Campylobacter or Salmonella $(p=0.06)$, 2.8 times more likely to test positive for $V$. cholerae or $V$. parahaemolyticus $(p=0.02), 1.8$ times more likely to test positive for $C$. difficile $(p=0.1)$ and 2.2 times more likely to be infected with any opportunistic pathogen excluding $V i b$ rio or Plesiomonas spp. ( $p=0.05)$. In contrast, negative correlations were detected between isolation of $V$. alginolyticus and exposure to heavy freshwater runoff $(p=0.06)$. Trends for sewage contact were unclear because no otters were obtained from areas with high municipal sewage exposure. Animals with moderate sewage exposure were twice as likely to test positive for $V$. cholerae or $V$. parahaemolyticus $(p=0.05)$, but less likely to test positive for $V$. alginolyticus or $C$. difficile than otters with low sewage exposure ( $p=0.03$ and $p=0.007$ respectively). Otters sampled during the wet season were 1.7 times more likely to test positive for $C$. perfringens $(p=0.07)$, but half as likely to test positive for $V$. cholerae or $V$. parahaemolyticus $(p=0.04)$ and $V$. alginolyticus $(p=0.09)$.

\subsubsection{Multivariate analyses}

Results are summarized in Table II. Dead otters were 3.2 times more likely to test positive for Salmonella or Campylobacter $(p=0.06)$, 7.3 times more likely to test positive for $C$. perfringens $(p<0.001)$ and 2.3 times more likely to be infected with $\geq 1$ opportunistic pathogen $(p=0.007)$ than live otters, but were less likely to test positive for $V$. alginolyticus $(p=0.001)$. Males were 2.7 times more likely to be infected with $V$. cholerae or $V$. parahaemolyticus $(p=0.01)$, but less likely to test positive for $V$. alginolyticus or $C$. difficile ( $p=0.004$ and 0.04 respectively). Otters from more urbanized regions (like Monterey or Estero Bay) were 4.6 times more likely to test positive for Campylobacter or Salmonella $(p=0.09), 3.9$ times more likely to test positive for $V$. cholerae or $V$. parahaemolyticus $(p=0.03), 5.7$ times more likely to test positive for $P$. shigelloides $(p=0.05)$ and 2.3 times more likely to be infected with $\geq 1$ opportunistic pathogen $(p=0.07)$ than otters from areas with undeveloped coastlines (like the Big Sur coast). Otters sampled near regions of high freshwater runoff were 3.1 times more likely to test positive for Campylobacter or Salmonella $(p=0.1), 2.7$ times more likely to test positive for $V$. cholerae or $V$. parahaemolyticus $(p=0.04)$ and 2.1 times more likely to be infected with $\geq 1$ enteric pathogen $(p=0.09)$ compared to otters from regions with low freshwater outflow. Clostridium perfringens was 2.7 times more likely to be isolated from otters during the rainy season $(p=0.004)$, while $V$. alginolyticus was 3 times more likely to be isolated from dry season otters $(p=0.002)$.

\subsubsection{Spatial analyses}

A $1.4 \mathrm{~km}$ diameter cluster of $C$. perfringensinfected otters was located near the Salinas River mouth in south-central Monterey Bay; 7 of 8 otters from this region were infected, while only 2.3 were expected if $C$. perfringens exposure was equivalent across all portions of the sea otter range $(p=0.085)$. In contrast, a $3.9 \mathrm{~km}$, low-risk cluster for $C$. perfringens was identified near Morro Bay; no otters from this region tested positive for $C$. perfringens, although 6 were predicted $(p=0.035)$. A $5.2 \mathrm{~km}$, low-risk site for otter infection by $C$. difficile was detected north of Morro Bay near Cayucos; no otters from this area tested positive for $C$. difficile, although 7 were predicted $(p=0.003)$. A $10.6 \mathrm{~km}$ diameter, "low-risk" site for otter infection by $V$. alginolyticus was located north of the outflow 
Table II. Multivariate analysis of risk factors associated with detection of opportunistic enteric bacterial pathogens in sea otter feces.

\begin{tabular}{|c|c|c|c|c|c|c|c|c|c|c|c|c|c|c|c|c|}
\hline \multirow[t]{3}{*}{ Risk factors } & & \multirow[t]{3}{*}{$n$} & \multicolumn{14}{|c|}{ Bacterial groups } \\
\hline & & & \multicolumn{2}{|c|}{$\begin{array}{c}\text { Campylobacter } \\
\text { or Salmonella } \\
\text { spp. } \\
\end{array}$} & \multicolumn{2}{|c|}{$\begin{array}{l}\text { V. cholerae or } \\
\text { V. parahaemolytcus }\end{array}$} & \multicolumn{2}{|c|}{ C. perfringens } & \multicolumn{2}{|c|}{ C. difficile } & \multicolumn{2}{|c|}{ P. shigelloides } & \multicolumn{2}{|c|}{ V. alginolyticus } & \multicolumn{2}{|c|}{$\begin{array}{l}\text { All pathogens, no } \\
\text { V. alginolyticus or } \\
\text { Plesiomonas } \\
\end{array}$} \\
\hline & & & $\mathrm{OR}^{\mathrm{a}}$ & $p$ value & OR & $p$ value & OR & $p$ value & OR & $p$ value & OR & $p$ value & OR & $p$ value & OR & $p$ value \\
\hline \multirow{2}{*}{$\begin{array}{l}\text { Live-dead } \\
\text { status }\end{array}$} & Live & 137 & 1 & - & & & 1 & - & & & & & 1 & - & 1 & - \\
\hline & Dead & 107 & 3.2 & $0.06^{\mathrm{b}}$ & & & 7.3 & $<0.001^{\mathrm{b}}$ & & & & & 0.2 & $0.001^{\mathrm{b}}$ & 2.3 & $0.007^{\mathrm{b}}$ \\
\hline \multirow[t]{2}{*}{ Gender } & Female & 125 & & & 1 & - & & & 1 & - & & & 1 & - & & \\
\hline & Male & 92 & & & 2.7 & $0.01^{\mathrm{b}}$ & & & 0.5 & $0.04^{\mathrm{b}}$ & & & 0.3 & $0.004^{\mathrm{b}}$ & & \\
\hline \multirow{4}{*}{$\begin{array}{l}\text { Human } \\
\text { population }\end{array}$} & $<100$ & 70 & 1 & - & 1 & - & & & & & 1 & - & & & 1 & - \\
\hline & $100-1000$ & 99 & 2 & 0.4 & 3.2 & $0.04^{\mathrm{b}}$ & & & & & 1.1 & 0.9 & & & 2 & $0.05^{\mathrm{b}}$ \\
\hline & $1000-3000$ & 40 & 2.4 & 0.4 & 5 & $0.007^{\mathrm{b}}$ & & & & & 2.8 & 0.3 & & & 2.3 & $0.07^{\mathrm{b}}$ \\
\hline & $>3000$ & 35 & 4.6 & $0.09^{\mathrm{b}}$ & 3.9 & $0.03^{\mathrm{b}}$ & & & & & 5.7 & $0.05^{\mathrm{b}}$ & & & 2.3 & $0.07^{\mathrm{b}}$ \\
\hline \multirow{3}{*}{$\begin{array}{l}\text { Freshwater } \\
\text { outflow }\end{array}$} & Low & 148 & 1 & - & 1 & - & & & & & & & & & 1 & - \\
\hline & Medium & 63 & 1.3 & 0.7 & 1.7 & 0.2 & & & & & & & & & 1.6 & 0.2 \\
\hline & High & 33 & 3.1 & $0.1^{\mathrm{b}}$ & 2.7 & $0.04^{\mathrm{b}}$ & & & & & & & & & 2.1 & $0.09^{\mathrm{b}}$ \\
\hline \multirow[t]{2}{*}{ Season } & Dry & 139 & & & & & 1 & - & & & & & 1 & - & & \\
\hline & Wet & 115 & & & & & 2.7 & $0.004^{\mathrm{b}}$ & & & & & 0.3 & $0.002^{\mathrm{b}}$ & & \\
\hline
\end{tabular}

${ }^{\mathrm{a}} \mathrm{OR}=$ odds ratio.

${ }^{\mathrm{b}}$ Significantly different than reference category based on $p$ values $\leq 0.1$. 
of the Pajaro and Salinas Rivers in north-central Monterey Bay; no animals from this area tested positive for $V$. alginolyticus where 6 cases were predicted $(p=0.036)$. Finally, a large (15.6 km diameter), low-risk site for otter infection by Salmonella, C. perfringens, C. difficile, Campylobacter, $V$. parahaemolyticus and/or $V$. cholerae was detected along the minimally urbanized "Big Sur" coast (Fig. 1); no otters from this region were infected by the above bacteria, although 7 isolations were predicted $(p=0.007)$. No significant space-time clusters were identified for necropsied otters.

\section{DISCUSSION}

Here we summarize the range of enteric bacterial pathogens infecting southern sea otters, including both classic fecal indicators (Salmonella, Campylobacter, C. perfringens, C. difficile and E. coli O157:H7) and species that are more typically associated with water contact or consumption of food harvested from aquatic environments (Vibrio spp. and P. shigelloides). Our findings in sea otters were similar to reports of the prevalence of opportunistic enteric bacterial pathogens in marine invertebrates [1, 16, 22, 29, 30] (Tab. III). Miller et al. [29] tested marine and estuarine invertebrates from central California for contamination by Salmonella, Campylobacter, Vibrio, C. perfringens and $P$. shigelloides, facilitating comparison of enteric bacterial prevalence between sea otters and their invertebrate prey. Over $80 \%$ of mussel (Mytilus californianus) batches were positive for at least one enteric bacterial pathogen. The most common bacteria in marine invertebrates and sea otters were $C$. perfringens and Vibrio spp., including V. parahaemolyticus, non-O1 $V$. cholerae and $V$. alginolyticus. However, Salmonella spp. detection was uncommon in both groups. Of the various bacteria above, only E. coli $\mathrm{O} 157: \mathrm{H} 7$ was never identified from sea otters or marine invertebrates [29], although this pathogen was recently traced to produce grown in coastal croplands draining into prime sea otter habitat [7].

Based on reports demonstrating that sea otters are excellent environmental sentinels
[24-26], we predicted that isolation of these opportunistic bacterial pathogens from sea otter feces would be more common in otters with greater exposure to freshwater runoff, sewage or more urbanized coastlines. Indeed, otters sampled near urbanized areas or regions with high freshwater runoff were more likely to test positive (Tab. II). Other significant risk factors for bacterial isolation included male sex, sample season (wet or dry, depending on the bacteria of interest) and otters that died. The increased risk observed for males may be due to greater rangewide movement, leading to higher exposure to coastal point-sources of pathogen contamination, and stress due to competition for mates, food and territories.

Freshwater runoff has also been significantly associated with Toxoplasma gondii infection in sea otters [24]; the most likely source of exposure is water or prey contamination by feces from wild and domestic felids. Indeed, unique T. gondii strains shared by terrestrial carnivores, shellfish and sea otters have been identified [25]. Exposure to freshwater runoff and recent coastal precipitation were also risk factors for detection of Cryptosporidium and Giardia in California mussels [28] (Tab. III). The range of bacteria isolated from otter feces during the wet and dry seasons were similar to those isolated from sympatric marine invertebrates (Tab. III). Invertebrates collected inside muddy embayments were more often positive for opportunistic enteric bacteria than those living in sandy areas, and freshwater clams collected close to the ocean were more likely to test positive than those collected further upstream [29] (Tab. III). Suspended mussels and benthic invertebrates from the same location were often culture-positive at the same time, suggesting that bacteria were passing through in the water column. Collectively, these findings suggest that bacterial contamination of invertebrates occurs commonly along interfaces between fresh and saltwater; these nearshore areas are favored habitat for sea otters.

The importance of surface runoff as a contributor of fecal pollution is emphasized by the fact that the largest river in central California discharges 432 times more untreated water to the ocean every year than the largest 
Table III. Environmental factors influencing detection of pathogenic bacteria or protozoa in sea otters and freshwater or marine invertebrates from coastal California.

\begin{tabular}{|c|c|c|c|c|c|c|c|c|c|c|}
\hline \multirow[t]{2}{*}{ Pathogen group } & \multirow{2}{*}{$\begin{array}{l}\text { Sample } \\
\text { type }\end{array}$} & \multicolumn{9}{|c|}{ Risk factor } \\
\hline & & $\begin{array}{l}\text { Freshwater } \\
\text { runoff }\end{array}$ & $\begin{array}{c}\text { Coastal } \\
\text { urbanization }\end{array}$ & $\begin{array}{l}\text { Municipal } \\
\text { sewage }\end{array}$ & $\begin{array}{c}\text { Other } \\
\text { anthropogenic } \\
\text { sewage sources }\end{array}$ & $\begin{array}{l}\text { Domestic } \\
\text { animal } \\
\text { waste }\end{array}$ & $\begin{array}{c}\text { Wet } \\
\text { season }\end{array}$ & $\begin{array}{l}\text { Recent } \\
\text { precip. }\end{array}$ & $\begin{array}{l}\text { Water } \\
\text { temp. } \\
>12{ }^{\circ} \mathrm{C}\end{array}$ & Reference \\
\hline Fecal enteric bacteria & $\begin{array}{l}\text { Freshwater } \\
\text { clams }\end{array}$ & - & - & - & - & - & $\downarrow, \pm, *, \dagger$ & - & - & [28] \\
\hline $\begin{array}{l}\text { Salmonella, } \\
\text { Campylobacter }\end{array}$ & $\begin{array}{l}\text { Marine } \\
\text { invertebrates }\end{array}$ & $\leftrightarrow$ & $\leftrightarrow$ & - & $\uparrow$ & $\uparrow$ & $\uparrow$ & $\downarrow$ & $\downarrow$ & [28] \\
\hline $\begin{array}{l}\text { Clostridium } \\
\text { perfringens, } \\
\text { C. difficile }\end{array}$ & Sea otters & $\uparrow$ & $\uparrow$ & \pm & - & - & $\uparrow, \leftrightarrow$ & - & - & $\begin{array}{l}\text { Current } \\
\text { study }\end{array}$ \\
\hline $\begin{array}{l}\text { Estuarine/marine } \\
\text { bacteria }\end{array}$ & $\begin{array}{l}\text { Freshwater } \\
\text { clams }\end{array}$ & - & - & - & - & - & $\downarrow$ & - & - & {$[28]$} \\
\hline $\begin{array}{l}\text { Vibrio cholerae, } \\
\text { V. parahemolyticus }\end{array}$ & $\begin{array}{l}\text { Marine } \\
\text { invertebrates }\end{array}$ & $\leftrightarrow$ & $\leftrightarrow$ & - & $\uparrow$ & $\uparrow, \downarrow$ & $\downarrow, \leftrightarrow$ & $\downarrow, \leftrightarrow$ & $\uparrow, \leftrightarrow$ & {$[28]$} \\
\hline $\begin{array}{l}\text { V. alginolyticus, } \\
\text { P. shigelloides }\end{array}$ & Sea otters & $\uparrow, \leftrightarrow$ & $\uparrow, \leftrightarrow$ & \pm & - & - & $\downarrow, \leftrightarrow$ & - & - & $\begin{array}{l}\text { Current } \\
\text { study }\end{array}$ \\
\hline Protozoa & $\begin{array}{l}\text { Freshwater } \\
\text { clams }\end{array}$ & - & $\leftrightarrow$ & $\leftrightarrow$ & - & - & $\uparrow$ & $\leftrightarrow$ & - & [26] \\
\hline Cryptosporidium & $\begin{array}{l}\text { Marine } \\
\text { invertebrates }\end{array}$ & $\uparrow$ & - & - & $\leftrightarrow$ & $\leftrightarrow$ & $\leftrightarrow$ & $\uparrow$ & - & [27] \\
\hline Giardia & $\begin{array}{l}\text { Freshwater } \\
\text { clams }\end{array}$ & - & $\leftrightarrow$ & $\leftrightarrow$ & - & - & $\uparrow$ & $\leftrightarrow$ & - & [26] \\
\hline Toxoplasma gondii & Sea otters & $\uparrow$ & $\leftrightarrow$ & $\leftrightarrow$ & - & - & $\leftrightarrow$ & - & - & [23] \\
\hline Sarcocystis neurona & Sea otters & $\uparrow$ & - & - & - & - & $\uparrow$ & $\uparrow$ & - & {$[25]$} \\
\hline
\end{tabular}

$*, \uparrow=$ Exposure to the risk factor resulted in an enhanced risk of bacterial detection; $\downarrow=$ Exposure resulted in a decreased risk of detection; $\leftrightarrow=$ No affect on risk of detection; $\pm=$ Dataset insufficient to evaluate associations; $-=$ Not evaluated; and $\dagger=$ In cases where $>1$ possible outcome is listed, outcomes varied by bacterial species or group. 
municipal sewage plant (Central Coast Water Quality Control Board, unpublished data). Land-based fecal deposition by pets, livestock and terrestrial wildlife inhabiting coastal watersheds may be substantial; in one coastal California community, fecal deposition by domestic cats alone was estimated at 107 metric tones/ year, or $26 \mathrm{~kg} / \mathrm{ha}$ [8]. When nearshore marine environments are contaminated with feces for prolonged periods, opportunistic enteric bacteria may concentrate in sediments, invertebrate biota and resident vertebrates $[9,10,21]$. Colonization of zooplankton and suspended marine particles by Vibrio, Salmonella and Campylobacter has been reported [20, 22, 40], suggesting additional means for bacterial dissemination in marine habitats.

Associations between bacterial pathogen detection in sea otters and exposure to municipal sewage could not be determined in this study, because no otters were obtained from areas exposed to heavy discharges of municipal sewage. Additional nearshore fecal loading due to sewage spills, agricultural impoundments, septic tanks, lawns, pastures, hardscape and boats were not accounted for in this study.

In the current study, coastal urbanization proved to be an important risk factor for opportunistic enteric bacterial infection of sea otters. An increased density of paved surfaces in urbanized communities has been linked with negative impacts to local waterways: Young and Thackston [42] found that streams in residential communities with increased hardscape had higher bacterial loads during storms than those from less developed communities. Paved surfaces such as parking lots, streets and sidewalks may facilitate land-sea transport of pet waste. Other factors that could promote bacterial contamination of water located adjacent to urbanized coastlines include fertilizer runoff (through nutrient enrichment), discharges of heated water, or algal blooms that can trigger explosive bacterial proliferation through enhanced bioavailability of dissolved organic material [20, 30].

Some interesting trends were noted for the various groups of enteric pathogens isolated from sea otters. C. perfringens was more commonly isolated from otters during the cold, wet season, similar to prior reports for sympatric freshwater and marine invertebrates [29] (Tab. III). This finding could be due to greater downstream flushing during winter or more favorable conditions for $C$. perfringens survival [9]. Postmortem proliferation likely contributed to higher detection of this bacterium in feces from necropsied otters. $C$. perfringens appears to be part of the normal anaerobic microflora of otters and other marine species [3], but it can also be an opportunistic pathogen [33, 36, 39, 41] and C. perfringens-associated necrotizing enteritis was occasionally observed in our sample of necropsied otters.

This is the first report of isolation of both C. difficile and Campylobacter spp. from sea otters. The prevalence of $C$. difficile infection was significantly higher in dead otters, suggesting possible disease implications and/or postmortem overgrowth. Common terrestrial hosts for $C$. difficile include dogs, horses, humans and wildlife, and asymptomatic fecal shedding is common [13]. The majority of Campylobacter isolates were $C$. lari-like and $C$. coli, along with some less well characterized strains. Environmental sources for Campylobacter include sewage, urban or farm runoff and birds [1, 13]. Contamination of shellfish beds by $C$. jeju$n i$ has been reported from California, Washington and Oregon [1, 29]. The pathogenicity of Campylobacter spp. for some terrestrial mustellids is well established $[4,12]$; in the current study, a few necropsied sea otters with enteric Campylobacter infections exhibited mild intestinal mural thickening. A higher prevalence of fecal shedding of C. jejuni (48.5\%) was reported for sick, stranded elephant seals (Mirounga angustirostris) in California, compared to healthy seals $(13.3 \%)$ [37].

Enteric Salmonella infection was uncommon in sea otters $(<1.0 \%)$ compared to the frequency of detection in sympatric terrestrial and marine vertebrates [11, 35-37, 39]. A high prevalence of Salmonella infection (13.6\%) was reported in California sea lions [37] and sick, stranded elephant seals were 41 times more likely to test positive for Salmonella than natal-site seals [39]. Salmonella contamination has been demonstrated in mussels (Mytilus spp.), oysters (Ostrea edulis), clams (Corbicula 
spp.) and cockles (Cerastoderma spp.), even at fecal coliform concentrations below regulatory levels for human consumption. In a survey of marine invertebrates from coastal California, $S$. Typhimurium and $S$. Heidelberg were isolated from Pismo clams (Tivela stultorum) and fat innkeeper worms (Eurechis caupo) [29].

In the current study, nearly all Salmonellainfected otters were recovered near pinniped rookeries, where densely packed, immunologically naive pinnipeds may experience enhanced fecal shedding of facultative pathogens. Salmonella enterica serovars reported from Pacific coastal marine mammals and birds include $S$. Typhimurium, $S$. Enteriditis, $S$. Newport, $S$. Saint Paul, $S$. Adelaide, $S$. Dublin, $S$. Hadar, $S$. Johannesburg, $S$. Montevideo and $S$. Ohio [11, 35-37, 39]. Infection by Salmonella Newport appears to be especially prevalent among California wildlife. Salmonella Typhimurium, $S$. Newport, $S$. Enteriditis, S. Saint Paul and nontypeable Salmonella spp. have all been isolated from sea otters [35], including a few animals in the present study with lesions of enteritis, intestinal volvulus and/or septicemia. However, some clinically normal sea otters also tested positive. Salmonella infections in other marine species have been associated with enteritis, cholecystitis, abscesses, pneumonia and septicemia [11, 35, 37, 39].

Sea otters sampled during the dry season were more likely to test positive for $V$. cholerae, $V$. parahaemolyticus and $V$. alginolyticus, similar to findings for sympatric freshwater and marine invertebrates (Tab. III). Many Vibrio spp. reach peak numbers in water, sediment and invertebrates during the summer $[15,16$, 23] and high isolation rates from otters may reflect high environmental exposure. In California, non-01 $V$. cholerae numbers may increase 5 to 56-fold during summer, with the highest concentrations in waterways with the greatest fecal pollution, as indicated by total coliform counts [16]. Isolated from $19 \%$ of otters, $V$. parahaemolyticus is the single most common cause of seafood-associated human illness in the USA [38]. This bacterium is cosmopolitan in saline and brackish water; human disease is commonly associated with consumption of raw or undercooked shellfish harvested from waters $>15{ }^{\circ} \mathrm{C}$ [23]. Vibrio parahaemolyticus has been isolated from a wide range of invertebrates and can proliferate in shellfish, increasing 790 -fold within $24 \mathrm{~h}$ at $26^{\circ} \mathrm{C}[29,38]$. In the current study, systemic $V$. parahaemolyticus or related Vibrio spp. infections were detected in some otters with lesions of enteritis and septicemia.

Vibrio alginolyticus and the related bacterium $V$. fluvialis were obtained primarily from feces of live otters captured during periods of decreased precipitation, and from otters inhabiting regions that were less impacted by surface runoff or coastal urbanization, such as the Big Sur coast. Thus, fecal isolation of $V$. alginolyticus and $V$. fluvialis appeared to be representative of live, ostensibly healthy otters from more pristine habitats that were likely to be actively feeding when sampled. For other marine wildlife, isolation of $V$. alginolyticus is relatively common and pathogenicity appears to be relatively low $[5,6,11,39]$. However, a few sea otters in the current study exhibited lesions of septicemia in association with isolation of $V$. alginolyticus from multiple tissues. Isolation of $V$. alginolyticus from marine invertebrates was positively correlated with salinity and inversely correlated with precipitation [29], suggesting that this bacterium prefers saline habitat with minimal freshwater influence.

Plesiomonas shigelloides was isolated from 15 otters. Like the Vibrios, P. shigelloides is endemic to estuarine and marine habitats and can be an opportunistic pathogen [14]. The degree of pathogenicity of $P$. shigelloides for marine mammals is debated, although $P$. shigelloides has been isolated from feces, lungs, livers and brains of Pacific coastal pinnipeds [39]. It was occasionally isolated from the blood and viscera of necropsied sea otters in this study and was considered to be a weak opportunistic pathogen.

Our study findings offer insights for guiding public policy and management decisions regarding southern sea otter population recovery and coastal water quality. Our epidemiological data suggest that California otters are at highest risk of enteric infection by opportunistic bacterial pathogens when living near more urbanized coastlines, such as those along 
Monterey Bay, and regions with moderate to high freshwater runoff. Although our investigation was focused on sea otters, the potential impacts of this research extend well beyond otter health and conservation, because both sea otters and humans rely on the health of coastal ecosystems and the safety of marine foods for their survival.

Acknowledgements. We thank E. Berberich, D. Brownstein, L. Carswell, A. Fisher, H. Harris, B. Hatfield, M. Kenner, M. Murray, A. Schneider, M. Staedler, K. Starzel, T. Tinker and S. Toy-Choutka for sample collection. Financial support was provided by the California Department of Fish and Game, the Central Coast Regional Water Quality Control Board, the US Fish and Wildlife Service, Duke Power and the City of Pacific Grove. We acknowledge the Monterey Bay Aquarium, the Marine Mammal Center, USGSBRD, the United States Fish and Wildlife Service and CDFG for their efforts to recover and care for sick, stranded marine animals.

\section{REFERENCES}

[1] Abeyta C., Deeter F.G., Kaysner C.A., Stott R.F., Wekell M.M., Campylobacter jejuni in a Washington state shellfish growing bed associated with illness, J. Food Protect. (1993) 56:323-325.

[2] Altekruse S.F., Cohen M.L., Swerdlow D.L., Emerging foodborne diseases, Emerg. Infect. Dis. (1997) 3:285-293.

[3] Aschfalk A., Müller W., Clostridium perfringens toxin types in hooded seals in the Greenland Sea, determined by PCR and ELISA, J. Vet. Med. (2001) 48:765-769.

[4] Bell J.A., Manning D.D., Reproductive failure in mink and ferrets after intravenous or oral inoculation of Campylobacter jejuni, Can. J. Vet. Res. (1990) 4:432-437.

[5] Blake P.A., Vibrios on the half shell: what the walrus and carpenter didn't know, Ann. Intern. Med. (1983) 99:558-559.

[6] Buck J.D., Wells R.S., Rhinehart H.L., Hansen L.J., Aerobic microorganisms associated with freeranging bottlenose dolphins in coastal Gulf of Mexico and Atlantic Ocean waters, J. Wildl. Dis. (2006) 42:536-544.

[7] Cooley M., Carychao D., Crawford-Miksza L., Jay M.T., Myers C., Rose C., et al., Incidence and tracking of Escherichia coli $\mathrm{O} 157: \mathrm{H} 7$ in a major produce production region in California, PLoS ONE (2007) 2:e1159.

[8] Dabritz H.A., Atwill E.R., Gardner I.A., Miller M.A., Conrad P.A., Outdoor fecal deposition by freeroaming cats and attitudes of cat owners and nonowners toward stray pets, wildlife, and water pollution, J. Am. Vet. Med. Assoc. (2006) 229:74-81.

[9] Davies C.M., Long J.A., Donald M., Ashbolt N.J., Survival of fecal microorganisms in marine and freshwater sediments, Appl. Environ. Microbiol. (1995) 61:1888-1896.

[10] Edwards D.D., McFeters G.A., Venkatesan M.I., Distribution of Clostridium perfringens and fecal sterols in a benthic coastal marine environment influenced by the sewage outfall from McMurdo station, Antarctica, Appl. Environ. Microbiol. (1998) 64:2596-2600.

[11] Higgins R., Bacteria and fungi of marine mammals: a review, Can. Vet. J. (2000) 41:105-116.

[12] Hunter D.B., Prescott J.F., Hoover D.M., Hlywka G., Kerr J.A., Campylobacter colitis in ranch mink in Ontario, Can. J. Vet. Res. (1986) 50:47-53.

[13] Jones K., Howard S., Wallace J.S., Intermittent shedding of thermophilic Campylobacters by sheep at pasture, J. Appl. Microbiol. (1999) 86:531-536.

[14] Kain K., Kelly M.T., Clinical features, epidemiology, and treatment of Plesiomonas shigelloides diarrhea, J. Clin. Microbiol. (1989) 27:998-1001.

[15] Kaysner C.A., Abeyta C. Jr, Wekell M.M., DePaola A. Jr, Stott R.F., Leitch J.M., Incidence of Vibrio cholerae from estuaries of the United States West Coast, Appl. Environ. Microbiol. (1987) 53:1344-1348.

[16] Kenyon J.E., Piexoto D.R., Austin B., Gillies D.C., Seasonal variation in numbers of Vibrio cholerae (non-O1) isolated from California coastal waters, Appl. Environ. Microbiol. (1984) 47:1243-1245.

[17] Knap A., Dewailly E., Furgal C., Galvin J., Baden D., Bowen R.E., et al., Indicators of ocean health and human health: developing a research and monitoring network, Environ. Health Perspect. (2002) 110:839-845.

[18] Kulldorff M., Nagarwalla N., Spatial disease clusters: detection and inference, Stat. Med. (1995) 14:799-810.

[19] Kumar S., Shorenstein M.L., Niven N., Stroe M., Non-O1 Vibrio Cholerae gastroenteritis in Northern California, West. J. Med. (1984) 140:783-784.

[20] Lipp E.K., Huq A., Colwell R.R., Effects of global climate on infectious disease; the cholera model, Clin. Microbiol. Rev. (2002) 15:757-770. 
[21] Lisle J.T., Smith J.J., Edwards D.D., McFeters G.A., Occurrence of microbial indicators and Clostridium perfringens in wastewater, water column samples, sediments, drinking water and Weddell seal feces collected at McMurdo station, Antarctica, Appl. Environ. Microbiol. (2004) 70:7269-7296.

[22] Maugeri T.L., Carbone M., Fera M.T., Irrera G.P., Gugliandolo C., Distribution of potentially pathogenic bacteria as free living and planktonassociated in a marine coastal zone, J. Appl. Microbiol. (2004) 97:354-361.

[23] McLaughlin J.B., DePaola A., Bopp C.A., Martinek K.A., Napolilli N.P., Allison C.G., et al., Outbreak of Vibrio parahaemolyticus gastroenteritis associated with Alaskan oysters, N. Engl. J. Med. (2005) 353:1463-1470.

[24] Miller M.A., Gardner I.A., Packham A., Jessup D., Jameson R., Dodd E., Conrad P.A., Coastal freshwater runoff is a risk factor for Toxoplasma gondii infection in southern sea otters (Enhydra lutris nereis), Int. J. Parasitol. (2002) 32:997-1006.

[25] Miller M.A., Miller W.A., Conrad P.A., James E.R., Melli A.C., Leutenegger C.M., et al., Type X Toxoplasma gondii in a wild mussel and terrestrial carnivores from coastal California: new linkages between terrestrial mammals, runoff and toxoplasmosis of sea otters, Int. J. Parasitol. (2008) 34:275-284.

[26] Miller M.A., Conrad P.A., Harris M., Hatfield B., Langlois G., Jessup D.A., et al., Localized epizootic of meningoencephalitis in southern sea otters (Enhydra lutris nereis) caused by Sarcocystis neurona, Vet. Parasitol. (in press).

[27] Miller W.A., Atwill E.R., Gardner I.A., Miller M.A., Fritz H., Hedrick R.P., et al., Clams (Corbicula fluminea) as bioindicators of fecal contamination with Cryptosporidium and Giardia spp. in freshwater ecosystems in California, Int. J. Parasitol. (2005) 35:673-684.

[28] Miller W.A., Miller M.A., Gardner I.A., Atwill E.R., Harris M., Ames J., et al., New genotypes and factors associated with Cryptosporidium detection in mussels (Mytilus spp.) along the California coast, Int. J. Parasitol. (2005) 35:1103-1113.

[29] Miller W.A., Miller M.A., Gardner I.A., Atwill E.R., Byrne B.A., Jang S., et al., Salmonella spp., Vibrio spp., Clostridium perfringens and Plesiomonas shigelloides in freshwater and marine invertebrates from coastal California ecosystems, Microb. Ecol. (2006) 52:198-206.

[30] Mouriño-Pérez R.R., Worden A.Z., Azam F., Growth of Vibrio cholerae $\mathrm{O} 1$ in red tide waters off California, Appl. Environ. Microbiol. (2003) 69:6923-6931.
[31] Riedman M.L., Estes J.A., The sea otter (Enhydra lutris): behavior, ecology and natural history, U.S. Fish Wildl. Serv. Biol. Rep. (1990) 90: $1-26$.

[32] Schlundt J., Toyofuku H., Jansen J., Herbst S.A., Emerging food-borne zoonoses, Rev. Sci. Tech. (2004) 23:513-533.

[33] Schulman F.Y., Montali R.J., Hauer P.J., Gastroenteritis associated with Clostridium perfringens type $\mathrm{A}$ in black-footed ferrets (Mustela nigripes), Vet. Pathol. (2003) 30:308-310.

[34] Skanavis C., Yanko W.A., Clostridium perfringens as a potential indicator for the presence of sewage solids in marine sediments, Mar. Pollut. Bull. (2001) 42:31-35.

[35] Smith W.A., Mazet J.K., Hirsh D.C., Salmonella in California wildlife species: prevalence in rehabilitation centers and characterization of isolates, J. Zoo Wildl. Med. (2002) 33:228-235.

[36] Steele C.M., Brown R.N., Botzler R.G., Prevalence of zoonotic bacteria among seabirds in rehabilitation centers along the Pacific Coast of California and Washington, USA, J. Wildl. Dis. (2005) 41:735-744.

[37] Stoddard R.A., Gulland F.M., Atwill E.R., Lawrence J., Jang S., Conrad P.A., Salmonella and Campylobacter spp. in Northern elephant seals, California, Emerg. Infect. Dis. (2005) 11:1967-1969.

[38] Su Y.C., Liu C., Vibrio parahaemolyticus: a concern of seafood safety, Food Microbiol. (2007) 24:549-558.

[39] Thornton S.M., Nolan S., Gulland F.M., Bacterial isolates from California sea lions (Zalophus californianus), harbor seals (Phoca vitulina) and northern elephant seals (Mirounga angustirostris) admitted to a rehabilitation center along the central California coast, 1994-1995, J. Zoo Wildl. Med. (1998) 29:171-176.

[40] Venkateswaran K., Takai T., Navarro I.M., Nakano H., Hashimoto H., Siebeling R.J., Ecology of Vibrio cholerae non-O1 and Salmonella spp. and role of zooplankton in their seasonal distribution in Fukuyama coastal waters, Japan, Appl. Environ. Microbiol. (1989) 55:1591-1598.

[41] Williams C., Elnif J., Buddington R.K., The gastrointestinal bacteria of mink (Mustela vision L.): influence of age and diet, Acta Vet. Scand. (1998) 39:473-482.

[42] Young K.D., Thackston E.L., Housing density and bacterial loading in urban streams, J. Environ. Eng. (1999) 125:1177-1180. 